\title{
Helicobacter pylori-Negative Primary Rectal MALT Lymphoma: Complete Remission after Radiotherapy
}

\author{
Takuma Okamura $^{\mathrm{a}}$ Tomoaki Suga $^{\mathrm{a}}$ Yugo Iwaya $^{\mathrm{a}}$ \\ Tetsuya Ito $^{a}$ Shuichi Yokosawa ${ }^{a}$ Norikazu Arakurab \\ Hiroyoshi Ota ${ }^{c}$ Eiji Tanaka ${ }^{a}$ \\ ${ }^{a}$ Gastroenterology, Department of Medicine, Shinshu University School of \\ Medicine, ${ }^{b}$ Endoscopic Examination Center, Shinshu University Hospital, and \\ 'Department of Biomedical Sciences, School of Health Sciences, Shinshu \\ University School of Medicine, Matsumoto, Japan
}

\section{Key Words}

Helicobacter pylori-negative primary rectal MALT Iymphoma · Complete remission · Radiotherapy

\begin{abstract}
Rectal mucosa-associated lymphoid tissue (MALT) lymphoma is a rare condition. Although the majority of patients undergo surgical resection, a definitive treatment for rectal MALT lymphoma has not yet been established. In the present study, we report the outcome of radiotherapy in 3 patients with rectal MALT lymphoma. Our cohort ranged from 56 to 65 years of age. The male/female ratio was 1:2, and all patients were in stage I (Lugano classification) of the disease. Endoscopic findings revealed elevated lesions resembling submucosal tumors in 2 patients, and a sessile elevated lesion with a nodular surface in 1 patient. One of the 3 patients underwent magnifying endoscopy with crystal violet staining that demonstrated a type I pit pattern (Kudo's classification) lesion with a broad intervening area caused by the upthrust of the tumor from the submucosa. All patients tolerated radiotherapy at doses of $30 \mathrm{~Gy}$ without major complications and achieved complete remission. Follow-up ranged from 13 to 75 months (mean 51.0 months), revealing no recurrence of MALT lymphoma. As such, we propose radiotherapy to be a safe and effective means for treating rectal MALT lymphoma.
\end{abstract}




\section{Introduction}

Mucosa-associated lymphoid tissue (MALT) lymphoma was first described histologically by Isaacson and Wright in 1983 [1] and is now classified as an extranodal marginal zone B cell lymphoma of MALT type according to the World Health Organization classification. MALT lymphoma develops in diverse anatomic locations including the stomach, salivary gland, thyroid, lung, and breast. However, rectal involvement is extremely rare.

Current therapeutic options for rectal MALT lymphomas include surgical resection, endoscopic mucosal resection (EMR), antibiotic therapy (including Helicobacter pylori eradication), chemotherapy and radiotherapy. Since $H$. pylori infection plays an important role in the development of gastric MALT lymphoma, its eradication has become a first-line therapy for this disease. On the other hand, although the majority of early patients with rectal MALT lymphoma undergo surgical resection, a definitive treatment for rectal MALT lymphoma has not yet been established.

We here report 3 patients with $H$. pylori-negative primary rectal MALT lymphoma who achieved complete remission (CR) by radiotherapy, and review the existing literature on this treatment.

\section{Case Reports}

Patient 1

A 62-year-old woman underwent colonoscopy for further examination of occult blood in the stool. Colonoscopic examination revealed two elevated lesions 6 and $20 \mathrm{~mm}$ in diameter that resembled submucosal tumors in the lower rectum (fig. 1a). Magnifying endoscopy with crystal violet staining showed a type I pit pattern (Kudo's classification [2]) with a broad intervening area caused by the upthrust of the tumor from the submucosa (fig. 1b). Endoscopic ultrasonography showed a hypoechoic mass at the second and third layers (fig. 2a). Barium enema X-ray examination revealed an elevated lesion $20 \mathrm{~mm}$ in diameter in the lower rectum (fig. 2b). Histopathological examination of rectal biopsy specimens showed a diffuse proliferation of lymphoid cells of intermediate size with an irregular cleaved nucleus and moderate cytoplasm (centrocyte-like cells) (fig. 3a, b). Immunohistochemistry showed that the neoplastic cells were positive for CD20 (fig. 3c) but negative for CD3 (fig. 3d), CD5 and CD10. Neither B cell monoclonality nor the API2-MALT1 fusion gene were detected. No extraintestinal involvement was found on staging elevation, which included capsule endoscopy, double balloon enteroscopy, computed tomography, fluorodeoxyglucose positron emission tomography and bone marrow biopsy. Based on these findings, the diagnosis of stage I rectal MALT lymphoma (Lugano classification) was made. She had no weight loss, fever or night sweats. No lymphadenopathy was detected, and serum levels of soluble interleukin-2 receptor and beta2 microglobulin were within normal ranges. Upper gastrointestinal endoscopy revealed no abnormal findings and $H$. pylori was not detected in gastric biopsy specimens or biopsy specimen cultures. We therefore performed radiotherapy (total dose: $30 \mathrm{~Gy} / 20 \mathrm{fr}$ ), at the end of which colonoscopy revealed that the elevated lesions had disappeared and the site showed white scars (fig. 1c). Biopsy specimens demonstrated that small lymphocytes had decreased and the centrocyte-like cells had almost disappeared. Achievement of CR was confirmed by colonoscopic and histologic examinations. She has had no relapse in 13 months since radiotherapy.

Patient 2

A 65-year-old man underwent colonoscopy for further examination of a positive fecal occult blood test. He had undergone total gastrectomy for gastric cancer 5 years prior. Colonoscopic examination revealed an elevated lesion $10 \mathrm{~mm}$ in diameter with telangiectasia that resembled submucosal tumor in the lower rectum. Histopathological examination of rectal biopsy specimens showed a diffuse proliferation of centrocyte-like cells and glandular destruction with centrocyte-like 
cells (lymphoepithelial lesions), and the proliferating cells were phenotypically characterized as CD20+, CD3-, CD5- and bcl-2 \pm by immunohistochemical staging. Stage I rectal MALT lymphoma (Lugano classification) was diagnosed. The API2-MALT1 fusion gene was not detected, but B cell monoclonality was noted. Examination for serum H. pylori IgG antibody was negative. We performed radiotherapy (total dose: $30 \mathrm{~Gy} / 20 \mathrm{fr}$ ), at the end of which colonoscopy revealed that the elevated lesion had disappeared. CR was confirmed by colonoscopic and histologic examinations 1 month following treatment. Afterwards, the patient was followed closely by colonoscopy, but no relapse has been detected after 65 months.

\section{Patient 3}

A 56-year-old woman underwent colonoscopy due to hematochezia, which revealed a sessile elevated lesion $25 \mathrm{~mm}$ in diameter with a nodular surface in the upper rectum and a small elevated lesion $10 \mathrm{~mm}$ in diameter in the lower rectum. Although biopsy specimens showed diffuse proliferation of small atypical lymphocytes, it was difficult to distinguish MALT lymphoma from reactive lymphoreticular hyperplasia. EMR was performed on the sessile lesion to clarify the diagnosis. EMR specimens showed colonic mucosa with marked expansion of the lamina propria by centrocyte-like cells. Admixed were mature lymphocytes and plasma cells. Immunohistochemistry showed that the neoplastic cells were positive for CD20 and bcl-2, but negative for CD3, CD5, CD10 and cyclin D1. She was diagnosed as having stage I rectal MALT lymphoma (Lugano classification). Neither B cell monoclonality nor the API2-MALT1 fusion gene were detected. Upper gastrointestinal endoscopy revealed no abnormal findings and $H$. pylori was not detected in gastric biopsy specimens or biopsy specimen cultures. We administered radiotherapy (total dose: $30 \mathrm{~Gy} / 20 \mathrm{fr}$ ). Following treatment, colonoscopy revealed an EMR scar in the upper rectum and the absence of elevated lesion in the lower rectum. CR was confirmed by colonoscopic and histologic examinations. No relapse has been detected in 75 months.

\section{Discussion}

MALT lymphomas were first described histologically by Isaacson and Wright in 1983 [1] as diffuse infiltration of small lymphoid cells (centrocyte-like or monocytoid-looking cells), infiltration of lymphoma cells around the epithelium (lymphoepithelial lesions) and proliferation of plasma cells in the lamina propria of the mucosa. However, lymphoepithelial lesions are found with low frequency in colorectal MALT lymphomas. Primary colorectal lymphomas account for only about $0.2 \%$ of large intestinal malignancies, of which MALT lymphoma is the most common. Colorectal MALT lymphoma was most frequently found in the rectum [3]. Since rectal MALT lymphoma is very rare, its treatment has not been well investigated compared to that of gastric MALT lymphoma. Reported therapeutic options for rectal MALT lymphoma include surgical resection [4], EMR [4], H. pylori eradication [5, 6], chemotherapy [7] and radiotherapy.

Since MALT lymphoma tends to remain localized, the majority of early patients underwent surgical resection. However, as abdominoperineal resections were almost always necessary, patients' quality of life decreased following construction of an artificial anus. Some authors reported that EMR was useful for obtaining an accurate diagnosis [8]. Yet both the frequency of lymph node metastasis and the need for lymphadenectomy are not well known, and thus adoption of EMR as a therapeutic treatment is unreliable. Chemotherapy is not recommended for patients with localized MALT lymphomas as these tumors are less responsive to standard chemotherapy than aggressive lymphomas $[9,10]$.

H. pylori infection plays an important role in the development of gastric MALT lymphoma, and its eradication has become a first-line therapy for this disease. Several 
authors have performed antibiotic therapy on rectal MALT lymphoma patients regardless of $H$. pylori infection status and achieved CR [5, 6]. These reports suggested that the efficacy of eradication was not related with regression of rectal MALT lymphoma; namely, the development of rectal MALT lymphoma was due less to H. pylori infection and more to other microorganisms. This hypothesis remains unproven, however, and the rate of remission for antibiotic therapy has not been well investigated. Of the 16 reported patients with extragastric MALT lymphoma with $H$. pylori infection who underwent eradication, only one patient achieved regression, and the author suggested that antibiotic treatment targeting $H$. pylori should be discouraged in patients with extragastric MALT lymphomas [11]. In addition, the time to remission varies for this treatment; although one study reported that the median time to remission for colonic MALT lymphoma was 5.5 months [5], the schedule to evaluate treatment response and the timing of secondary treatment have not been determined. Antibiotic therapy may be attempted for patients with rectal MALT lymphoma regardless of $H$. pylori infection status before other treatment courses, but further studies on the efficacy of antibiotic therapy for rectal MALT lymphoma are warranted.

The radiosensitivity of MALT is well established, and radiotherapy has been found to be highly effective in controlling localized MALT lymphomas [9]. A total dose of $30 \mathrm{~Gy}$ is standard for the treatment of gastric MALT lymphoma. Other reports have suggested that $30 \mathrm{~Gy} / 20 \mathrm{fr}$ was appropriate for controlling extragastric MALT lymphomas without severe detrimental effects or serious local failure, particularly if the radiotherapy dose was less than $30 \mathrm{~Gy}[9,10]$. As toxicity after radiotherapy is related to total dose, radiation courses of 60-70 Gy may damage the intestinal tract [12]. Additionally, some authors have reported premature ovarian failure after radiotherapy (total dose: 30 Gy) [13]. Although the fertility of the patient must be considered, it is accepted that a total dose of $30 \mathrm{~Gy}$ is effective and safe.

We scanned the PubMed database for English language articles dated from 1973 to 2010 using the terms 'rectum' or 'colon', 'MALT' and 'radiotherapy'. Only 4 published cases of primary rectal MALT lymphoma treated with radiotherapy were found $[9,10,14,15]$, which are summarized along with our patients in table 1. Patient age ranged from 26 to 65 years (mean 53.8 years). The male/female ratio was 3:2. Endoscopic findings were elevated lesions resembling submucosal tumors in 4 patients. One patient had a sessile elevated lesion. All patients were in stage I (Lugano classification) of the disease at the time of diagnosis. API2-MALT1 fusion genes were not detected in any case. Although all patients were H. pylori-negative, eradication was performed on one patient. The patient's tumor diameter was long. The median radiation dose was 34.3 Gy (range 30-45 Gy). All patients tolerated the radiotherapy well with little acute toxicity. Follow-up ranged from 13 to 75 months (mean 44.3 months), revealing CR in 6 patients (85.7\%). All patients who achieved CR had no recurrence of the disease.

In conclusion, our results and those of previous reports suggest that radiotherapy at a total dose of $30 \mathrm{~Gy}$ is both effective and safe for treatment of rectal MALT lymphoma. Further studies are needed to determine the role of microorganisms in this disease and the possible merits of combined radiotherapy and antibiotic therapy. 


\section{Acknowledgement}

We thank Trevor Ralph for his English editorial assistance.

Table 1. Summary of primary rectal MALT lymphoma cases treated by radiotherapy reported in the English language literature

\begin{tabular}{|c|c|c|c|c|c|c|c|c|c|c|c|c|}
\hline $\begin{array}{l}\text { First author } \\
\text { [reference] }\end{array}$ & Year & $\begin{array}{l}\text { Age, } \\
\text { years }\end{array}$ & Sex & Symptoms & Endoscopic findings & $\begin{array}{l}\text { Stage } \\
\text { (Lugano } \\
\text { classification) }\end{array}$ & $\begin{array}{l}\text { API2- } \\
\text { MALT1 } \\
\text { fusion gene }\end{array}$ & $\mathrm{HP}$ & $\begin{array}{l}\text { Eradi- } \\
\text { cation }\end{array}$ & $\begin{array}{l}\text { Radio- } \\
\text { therapy } \\
\text { dose, Gy }\end{array}$ & $\begin{array}{l}\text { Out- } \\
\text { come }\end{array}$ & $\begin{array}{l}\text { Follow- } \\
\text { up, } \\
\text { months }\end{array}$ \\
\hline Tsang [10] & 2003 & ND & ND & ND & ND & I & ND & ND & ND & 35 & ND & $>48$ \\
\hline Yamashita [9] & 2008 & ND & ND & ND & ND & ND & ND & ND & ND & 30 & $\mathrm{CR}$ & ND \\
\hline Kobayashi [14] & 2008 & 26 & M & abdominal fullness & $\begin{array}{l}\text { hemorrhagic submucosal } \\
\text { tumor lesions }\end{array}$ & I & - & - & + & 40 & $\mathrm{CR}$ & 24 \\
\hline Foo [15] & 2008 & 60 & M & $\begin{array}{l}\text { constipation with } \\
\text { subsequent rectal } \\
\text { bleeding }\end{array}$ & large rectal tumor & I & ND & - & - & 45 & $\mathrm{CR}$ & 41 \\
\hline \multicolumn{13}{|l|}{ Our report } \\
\hline Case 1 & & 62 & $\mathrm{~F}$ & $\begin{array}{l}\text { occult stool blood } \\
\text { positive }\end{array}$ & $\begin{array}{l}\text { elevated submucosal tumor } \\
\text { lesions }\end{array}$ & I & - & - & - & 30 & $\mathrm{CR}$ & 13 \\
\hline Case 2 & & 65 & M & $\begin{array}{l}\text { occult stool blood } \\
\text { positive }\end{array}$ & $\begin{array}{l}\text { an elevated submucosal } \\
\text { tumor lesion }\end{array}$ & I & - & - & - & 30 & $\mathrm{CR}$ & 65 \\
\hline Case 3 & & 56 & $\mathrm{~F}$ & hematochezia & $\begin{array}{l}\text { sessile elevated lesion and } \\
\text { small elevated lesion }\end{array}$ & I & - & - & - & 30 & CR & 75 \\
\hline
\end{tabular}

$\mathrm{HP}=$ Helicobacter pylor $; \mathrm{ND}=$ not described; $\mathrm{M}=$ male; $\mathrm{F}=$ female; $\mathrm{CR}=$ complete remission . 


\begin{tabular}{r|l|l|l}
$\begin{array}{r}\text { Case Reports in } \\
\text { Gastroenterology }\end{array}$ & $\begin{array}{l}\text { Case Rep Gastroenterol 2012;6:319-327 } \\
\text { DOI: 10.1159/000339461 }\end{array}$ & $\begin{array}{l}\text { Published online: } \\
\text { May 30, 2012 }\end{array}$ & $\begin{array}{l}\text { @ 2012 S. Karger AG, Basel } \\
\text { ISSN 1662-0631 } \\
\text { www.karger.com/crg }\end{array}$ \\
\hline
\end{tabular}
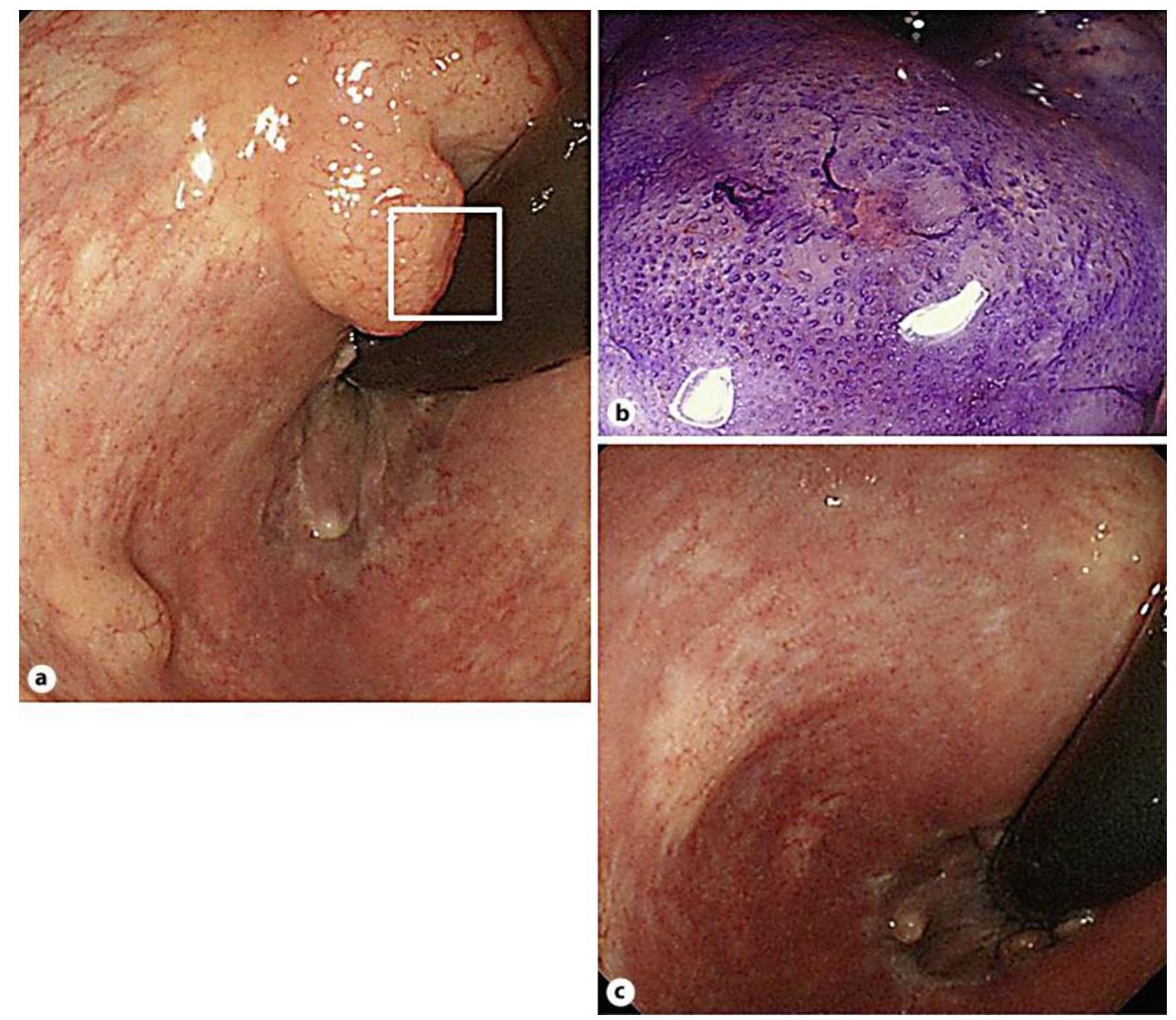

Fig. 1. a Colonoscopy revealed two lesions resembling submucosal tumors in the lower rectum. b Magnifying endoscopy with crystal violet staining of the box in a showed a type I pit pattern with a broad intervening area. c Colonoscopy after radiotherapy showed that the tumors had disappeared, and the site shows white scars. 


\begin{tabular}{r|l|l|l}
$\begin{array}{r}\text { Case Reports in } \\
\text { Gastroenterology }\end{array}$ & $\begin{array}{l}\text { Case Rep Gastroenterol 2012;6:319-327 } \\
\text { DOI: 10.1159/000339461 }\end{array}$ & $\begin{array}{l}\text { Published online: } \\
\text { May 30, 2012 }\end{array}$ & $\begin{array}{l}\text { @ 2012 S. Karger AG, Basel } \\
\text { ISSN 1662-0631 } \\
\text { www.karger.com/crg }\end{array}$ \\
\hline
\end{tabular}
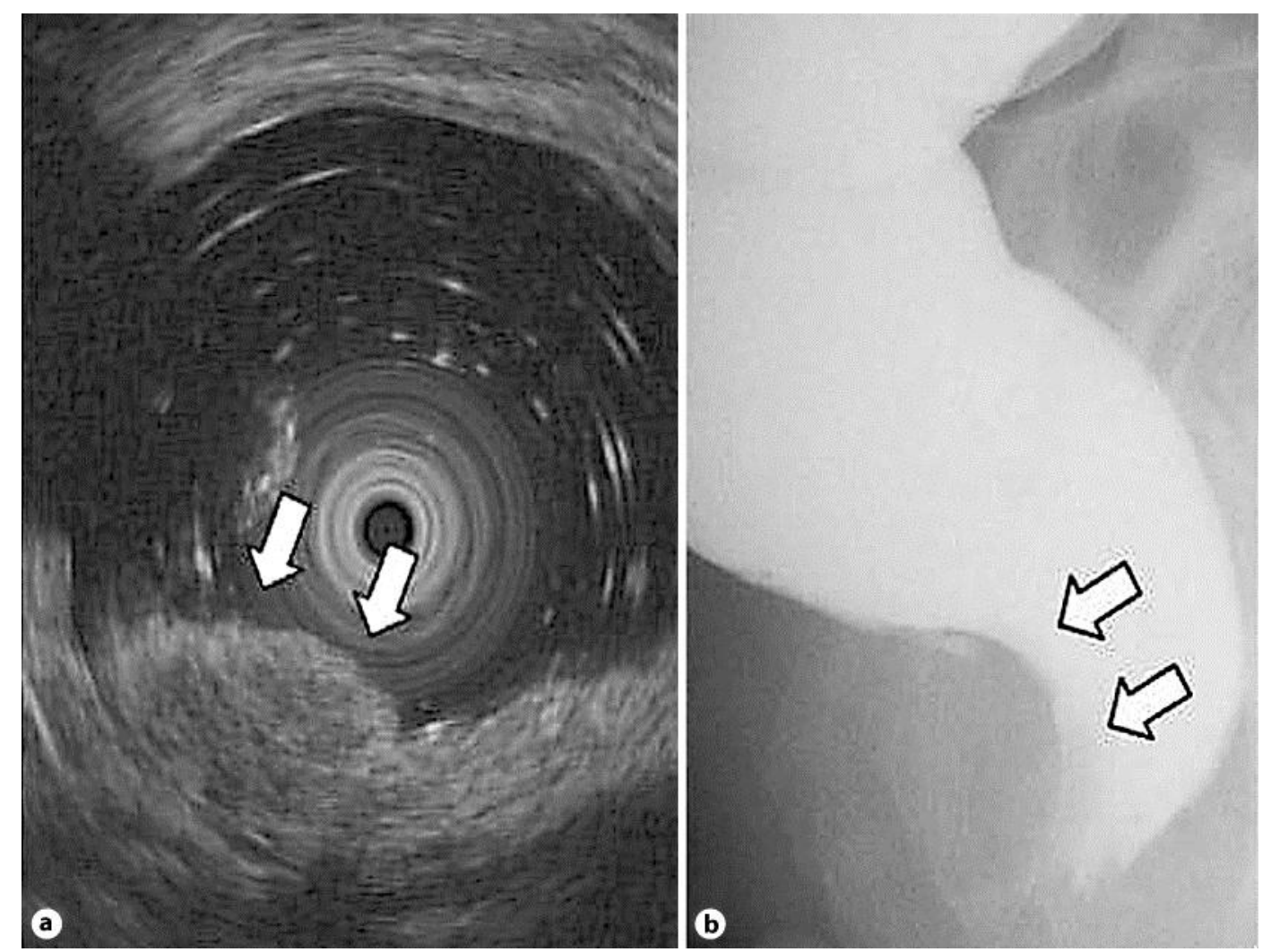

Fig. 2. a Endoscopic ultrasonography showed a hypoechoic mass at the second and third layers (arrows). b Barium enema X-ray examination showed an elevated lesion in the lower rectum (arrows). 


\begin{tabular}{r|l|l|l}
$\begin{array}{r}\text { Case Reports in } \\
\text { Gastroenterology }\end{array}$ & $\begin{array}{l}\text { Case Rep Gastroenterol 2012;6:319-327 } \\
\text { DOl: 10.1159/000339461 }\end{array}$ & $\begin{array}{l}\text { Published online: } \\
\text { May 30, 2012 }\end{array}$ & $\begin{array}{l}\text { @ 2012 S. Karger AG, Basel } \\
\text { ISSN 1662-0631 } \\
\text { www.karger.com/crg }\end{array}$ \\
\hline
\end{tabular}

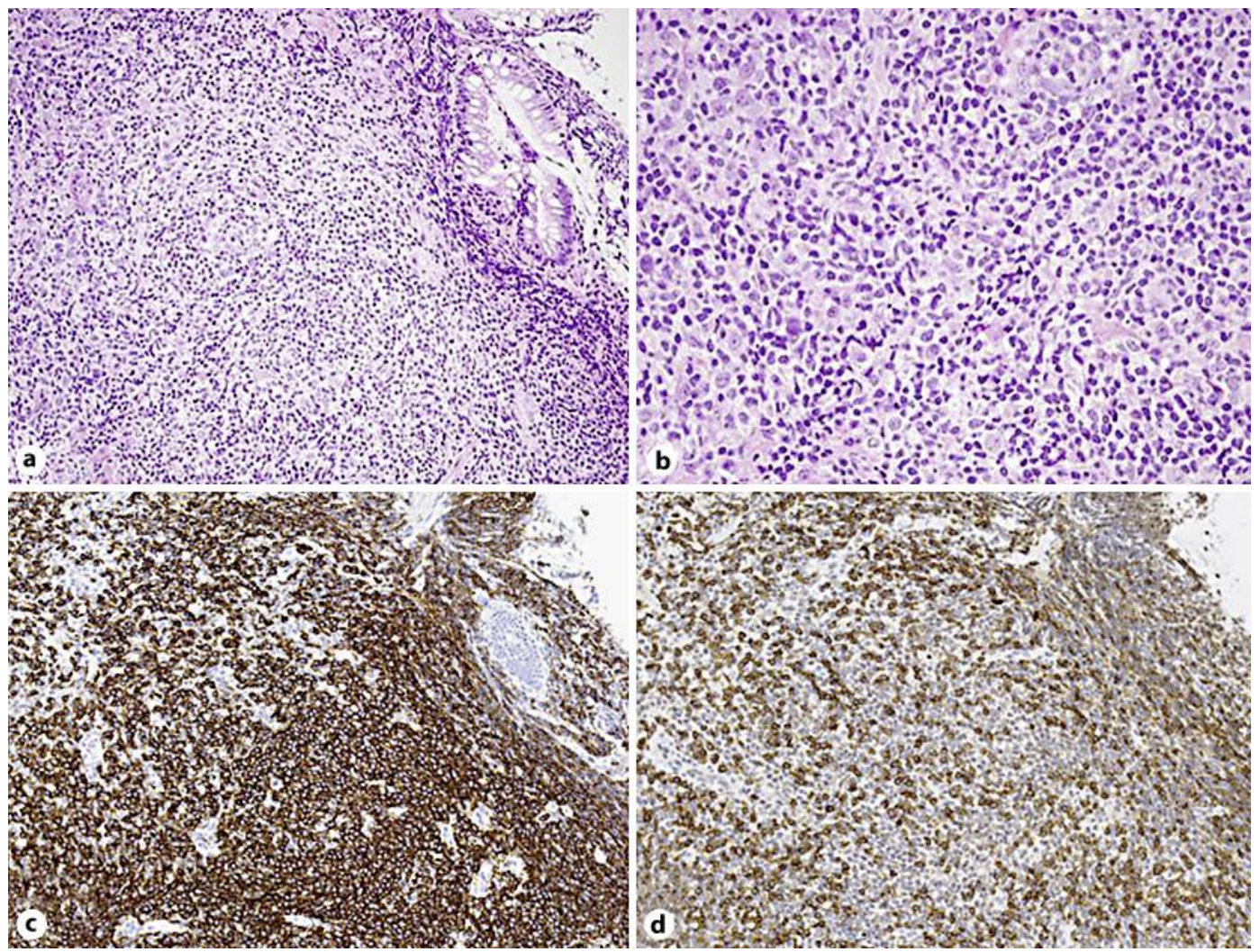

Fig. 3. a Microscopic findings of a rectal biopsy specimen showed diffuse proliferation of centrocyte-like cells (HE staining, original magnification $\times 20$ ). $\mathbf{b}$ High-power magnification of a (HE staining, original magnification $\times 100$ ). c CD20 immunohistochemical staining (original magnification $\times 20$ ). $\mathbf{d}$ CD3 immunohistochemical staining (original magnification $\times 20$ ).

\section{References}

1 Isaacson P, Wright DH: Malignant lymphoma of mucosa-associated lymphoid tissue: a distinctive type of B-cell lymphoma. Cancer 1983;52:1410-1416.

2 Kudo S, Rubio CA, Teixeira CR, et al: Pit pattern in colorectal neoplasia: endoscopic magnifying view. Endoscopy 2001;33:367-373.

-3 Sakugawa ST, Yoshino T, Nakamura S, et al: API2-MALT1 fusion gene in colorectal lymphoma. Mod Pathol 2003;16:1232-1241.

4 Matsumoto T, Shimizu M, Iida M, et al: Primary low-grade, B-cell, mucosa-associated lymphoid tissue lymphoma of the colorectum: clinical and colonoscopic features in six cases. Gastrointest Endosc 1998;48:501-508.

-5 Raderer M, Pfeffel F, Mannhalter C, et al: Regression of colonic low grade B cell lymphoma of the mucosa associated lymphoid tissue type after eradication of Helicobacter pylori. Gut 2000;46:133-135.

-6 Inoue F, Chiba T: Regression of MALT lymphoma of the rectum after anti-H. pylori therapy in a patient negative for H. pylori. Gastroenterology 1999;117:514-515.

7 Ghadir MR, Bakhshipour AR, Kolahdoozan SH: MALT lymphoma of the rectum: report of a case treated with chemotherapy. Govaresh 2009;14:127-130.

-8 Shami VM, Waxman I: Lymphoid follicular proctitis mimicking rectal lymphoma: diagnosis by EMR. Gastrointest Endosc 2004;60:648-652.

-9 Yamashita H, Nakagawa K, Asari T, et al: Radiotherapy for 41 patients with stages I and II MALT lymphoma: a retrospective study. Radiother Oncol 2008;87:412-417. 
10 Tsang RW, Gospodarowicz MK, Pintilie M, et al: Localized mucosa-associated lymphoid tissue lymphoma treated with radiation therapy has excellent clinical outcome. J Clin Oncol 2003;21:4157-4164.

11 Grunberger B, Wohrer S, Streubel B, et al: Antibiotic treatment is not effective in patients infected with Helicobacter pylori suffering from extragastric MALT lymphoma. J Clin Oncol 2006;24:1370-1375.

12 Kojima Y, Tashiro Y, Nagayasu K, et al: A case of radiation-induced giant rectal ulcer. Prog Dig Endosc 2010;76:108-109.

13 Yamamoto T, Shinji A, Mukawa K, et al: A case of rectal mucosa-associated lymphoid tissue lymphoma (MALT) successfully treated by radiation therapy (in Japanese). Nihon Shokakibyo Gakkai Zasshi 2011;108:1231-1236.

14 Kobayashi T, Takahashi N, Hagiwara Y, et al: Successful radiotherapy in a patient with primary rectal mucosa-associated lymphoid tissue lymphoma without the API2-MALT1 fusion gene: a case report and review of the literature. Leuk Res 2008;32:173-175.

15 Foo M, Chao MW, Gibbs P, et al: Successful treatment of mucosa-associated lymphoid tissue lymphoma of the rectum with radiation therapy: report of a case. Dis Colon Rectum 2008;51:1719-1723. 